\title{
Mengenal Kosmetik Pembersih Wajah Micellar Water dan Perkembangannya
}

\author{
Tazyinul Qoriah Alfauziah \\ Program Magister Farmasi, Fakultas Farmasi, Universitas Padjadjaran, Sumedang 45363 \\ email: tazyinul95@gmail.com
}

\begin{abstract}
Abstrak :
Beberapa tahun belakangan, produk micellar water makin banyak ragamnya di pasaran. Hampir setiap perusahaan kosmetik terkemuka berlomba untuk membuat produk ini. Micellar water merupakan produk yang dibuat untuk membersihkan wajah maupun make-up. Micellar water menggunakan konsep tegangan permukaan untuk membersihkan wajah, karena selain mengandung air, micellar water juga mengandung surfaktan. Seiring makin majunya teknologi, mulai muncul istilah biphasic cosmetic atau produk kosmetik yang memiliki dua fase. Hal ini mulai merambah pada produk micellar water. Produk kosmetik memiliki waktu maksimal pemakaian setelah dibuka atau dikenal dengan istilah period after opening (PAO). Umumnya micellar water memiliki PAO selama 6 bulan karena komposisi utamanya adalah air, media dimana bakteri mudah untuk berkembang biak.
\end{abstract}

Keyword : kosmetik, pembersih wajah, micellar water

\section{Outline}

- Pendahuluan

- Sejarah micellar water

- Perkembangan micellar water : Biphasic micellar water

- Kesimpulan

\section{Pendahuluan}

Micellar water merupakan produk yang dibuat untuk membersihkan wajah maupun make-up. Sesuai dengan namanya, micellar water komponen utamanya air. Sehingga produk ini menawarkan konsumen untuk membersihkan wajah tanpa harus ke kamar mandi dan memakai sabun pencuci muka. Konon, salah satu produk micellar water ternama terjual tiap 6 detik di seluruh dunia [1]! Canggihnya lagi, konsep ini begitu berkembang hingga make-up mata dan bibir pun bisa dibersihkan dengan sekali usap.

\section{Sejarah micellar water}

Secara ilmiah, micellar water menggunakan konsep tegangan permukaan untuk membersihkan wajah, karena selain mengandung air, micellar water juga mengandung surfaktan (surfactant/surface active agent). 
Surfaktan adalah suatu kelompok senyawa yang memiliki gugus hidrofilik (suka air) dan gugus hidrofobik (tidak suka air), atau disebut juga ampifilik [2,3]. Karena strukturnya ini, surfaktan bisa berikatan dengan air dan minyak sekaligus. Oleh karena itu, senyawa ini juga banyak digunakan dalam produk kosmetik lainnya. Surfaktan bukanlah sesuatu yang baru ditemukan di era modern ini. Jangan heran, bahkan kosmetik mulai dikenal sekitar 10.000 - 8.000 BCE oleh masyarakat Mesir. Surfaktan mulanya digunakan sebagai bahan utama dari sabun, yang mulai diproduksi di Mesir sekitar tahun 3000 BCE dengan komposisi minyak zaitun dan thyme. Baru pada awal abad ke-7 CE, sabun diproduksi di Nablus, Kufa, dan Basra [4].

Surfaktan diklasifikasikan berdasarkan gugus hidrofiliknya menjadi surfaktan anionik, kationik, amfoterik, dan nonionik. Surfaktan anionik (gugus hidrofilik bermuatan negatif) banyak digunakan untuk produk detergen, pembersih pakaian, dan sampo karena sifat pembersihnya yang sangat baik. Surfaktan kationik (gugus hidrofiliki bermuatan positif) terkandung dalam keratin sehingga digunakan sebagai hair conditioner. Surfaktan nonionik, merupakan kelompok surfaktan yang paling banyak, tidak larut dalam larutan air. Karakteristik utamanya adalah baik untuk kulit dan kompatibel terhadap bagian mata. Biasanya tipe surfaktan ini digunakan sebagai cleansing agent (kombinasi dengan surfaktan anionik) dan emulsifier. Paling banyak digunakan pada produk bayi atau kulit sensitif $[3,4]$.

Diketahui bahwa surfaktan dapat menurunkan tegangan permukaan dan membentuk emulsi dari dua cairan yang berbeda kepolarannya (fase air dan fase minyak). Selain itu, fungsi surfaktan diantaranya adalah pembersih, pembasah, emulsifikasi, solubilisasi, dispersi, peningkat penetrasi, bahkan beberapa memiliki aktivitas antibakteri. Hampir setengah dari surfaktan yang ada, dipergunakan di sektor washing and cleaning $[2,3]$.

Surfaktan dalam micellar water akan membentuk suatu misel akibat bersatunya gugus hidrofobik di bagian inti misel karena berada pada medium air, seperti terlihat pada gambar. Saat diaplikasikan pada kapas, yang cenderung hidrofil, maka gugus hidrofob akan menghadap ke atas/udara. Kemudian kapas kita usapkan ke kulit wajah yang tersusun atas lipid, maka kotoran yang menempel akan tersapu secara sempurna [1]! Usut punya usut, micellar water pertama kali dikenal di Paris. Kala itu, wanita Paris beranggapan bahwa mencuci muka dengan air keran itu tidak sehat karena air keran kemungkinan mengandung bakteri. Oleh karena itu, terciptalah micellar water ini.

\section{Perkembangan micellar water : Biphasic micellar water}

Seiring makin majunya teknologi, mulai muncul istilah biphasic cosmetic atau produk kosmetik yang memiliki dua fase (two-phase composition). Hal ini mulai merambah pada produk micellar water.

Dilihat dari definisinya, biphase composition merupakan produk yang terdiri dari dua fase yang terlihat jelas, yaitu fase air dan fase minyak. Termasuk ke dalam sediaan emulsi, produk biphase composition ini memerlukan adanya pengocokan untuk membentuk emulsi sehingga terbentuk campuran yang homogen. 
Namun setelah dibiarkan beberapa lama, kedua fase akan terpisah kembali (dephasing/demixing). Dalam campuran ini, ditambahkan demixing agent seperti benzalkonium klorida, gluceth-10 hydroxypropyldimonium chloride [5]. Dalam biphase micellar water, tiap fase memiliki surfaktan agar dapat membersihkan wajah secara menyeluruh dan demixing agent terdapat pada fase air. Tergantung kecenderungan masing-masing produsen, produk biphase micellar water ini dirancang dengan warna kedua fase yang terlihat jelas atau keduanya dibuat transparan agar tidak terlihat bahwa ada perbedaan fase.

Dilihat dari fungsinya, biphase micellar water dapat menghapus kotoran yang larut air melalui fase airnya dan kotoran yang larut minyak atau kotoran waterproof melalui fase minyaknya. Selain itu, kebanyakan produk ini juga mengandung moisturizer, sehingga memiliki kemampuan untuk melembabkan kulit.

\section{Cara mengenali micellar water yang sudah tidak dapat dipakai (PAO)}

Perlu diketahui, bahwa produk kosmetik memiliki waktu maksimal pemakaian setelah dibuka atau dikenal dengan istilah period after opening (PAO). Pada tahun 2009, Europe Regulation mengeluarkan peraturan untuk produsen kosmetik agar mencantumkan PAO pada kemasan primer dan sekunder bila produk memiliki waktu kadaluarsa kurang dari 30 bulan [6]. Namun, karena bukan aturan internasional, kebanyakan kosmetik di Indonesia belum mencantumkan PAO pada kemasannya.

\section{Kesimpulan}

Umumnya micellar water memiliki PAO selama 6 bulan karena komposisi utamanya adalah air, media dimana bakteri mudah untuk berkembang biak. Selain itu, berikut ini beberapa tips untuk merawat kosmetik [7]:

- Bila mascaramu kering, buang! Jangan tambahkan air atau parahnya air liurmu supaya mascara basah kembali, karena air bisa memicu datangnya bakteri pada produkmu. Segera hubungi fasilitas kesehatan terdekat bila terjadi infeksi pada mata.

- Jangan berbagi make up, karena kamu mungkin sedang berbagi infeksi dengan orang lain. Produk uji yang digunakan di konter kosmetik juga bisa terkontaminasi, Iho! Jadi hati-hati menjaga kebersihan make up mu ya

- Simpan kosmetik secara baik dan benar. Misal, jangan dibiarkan kosmetik terpapar panas di dalam mobil karena panas dapat menyebabkan zat pengawet dalam kosmetik rusak sehingga bakteri dan jamur dapat tumbuh lebih cepat.

- Hati-hati kosmetik palsu! Beli kosmetik pada toko yang tepat dan terpercaya.

\section{Daftar Pustaka}

[1] Michelle M. What is micellar water and how does it works? Lab Muffin 2015. https://labmuffin.com/what-is-micellar-water-and-how-does-it-work/ (accessed October 28, 2018). 
[2] Lourith N, Kanlayavattanakul M. Natural surfactants used in cosmetics: Glycolipids. Int J Cosmet Sci 2009;31:255-61. doi:10.1111/j.1468-2494.2009.00493.x.

[3] Lukic M, Pantelic I, Savic S. An overview of novel surfactants for formulation of cosmetics with certain emphasis on acidic active substances. Tenside, Surfactants, Deterg 2016;53:7-19. doi:10.3139/113.110405.

[4] Dembitsky VM. Natural surfactants in cosmetics: From ancient times to present day. Inf - Int News Fats, Oils Relat Mater 2008;19:577-80.

[5] Touzan $P$, Lukasse $L$, Louvet $N$. TWO-PHASE COSMETIC OR DERMATOLOGICAL COMPOSTION. US5468496, 1995.

[6] Lionetti N, Rigano L. Labeling of Cosmetic Products. Cosmetics 2018;5. doi:10.3390/cosmetics5010022.

[7] USFDA. Shelf Life/Expiration Dating. FDA 2018. https://www.fda.gov/cosmetics/labeling/expirationdating/default.htm (accessed October $28,2018)$. 